Ann. Gén. Sél. anim., I977, 9 (4), 43I-447

\title{
Polydipsia and polyuria at high environmental temperature in association with the productive traits in the fowl
}

\author{
A. OBEIDAH, P. MÉRAT and A. BORDAS \\ Laboratoive de Génétique Factorielle, C.N.R.Z. \\ Centre National de Recherches Zootechniques, I.N.R.A. \\ 78350 Jouy-en-Josas
}

\section{Summary}

This work had the purpose to investigate the difference between normal birds and birds with high water consumption and water in feces, in the experimental flock, Jouy-en-Josas, in association with productive traits, body measurements, body temperatures and egg components at two different environmental temperatures. The results can be summarized as follows:

I. The difference between the two genotypes (polydipsic and normal) for water intake proved to be highly significant at the normal temperature $\left(20^{\circ} \mathrm{C}\right)$ and at the high environmental temperature $\left(27-34{ }^{\circ} \mathrm{C}\right.$ cycle), but it was more important in the first environment.

2. The difference between the two genotypes for water output proved to be significant in the normal condition. The same holds true with rectal temperature.

3. Body temperature measurements, rectal, comb and shank, were increased significantly for both genotypes at the high environmental temperature.

4. The polydipsic birds are less panting than the normal birds in the heated environment.

5. Egg weight and egg components are higher for the polydipsic birds in the normal condition.

6. Egg number is higher for polydipsic birds in the heated room.

7. Phenotypic correlations between traits were estimated within genotypes and treatments.

\section{Introduction}

A significant number of researches has been done to study the effect of environmental temperature on chickens and laying hens (see review by SMITH and OlIVER, I97I). Most of these researches discuss the response, to cold and hot conditions, of physiological parameters, mainly rectal temperature and respiration rate. The effect of environmental temperature on egg production and water consumption in laying White Leghorns has been studied by TosHro et al (1970).

Few works conversely relate to possible genetic influences on heat tolerance of laying hens. On the other hand, it is known that one of the ways for the hen to maintain its body temperature during heat stress is increasing its water intake and water evaporation by respiration. Water intake and output by laying hens has been, also, investigated by many workers (LEESON et al., 1976). The evidence 
for genetical influence on excessive water intake had been, firstly, reported by Buss and MURPHY (I965). That diabetes insipidus is an inherited character has been reported by WILLIAM and Buss (I968). They added that the kidneys of affected birds are capable of an antidiuretic response when lysine vasopressin or arginin vasotocin is injected. Meanwhile, the association between the productive traits and diabetes insipidus has been investigated to determine the effect of excessive and normal drinking on the economical traits (WIILIAM and BUSS, I968, SUE LINTERNMOORE, I972, EWALD et al., I967). Water output had been also studied in the same trend by Buss and MURPHY (I965), and RoBERT et al. (1974).

The principle of this study was, therefore, to investigate the effect of polydipsia and polyuria on the productive traits and egg components weights under normal and hot climatic conditions. The experiment was performed in order to determine which of the genotypes under study is more tolerant to heat.

\section{Material and Methods}

Since several years, two strains of the experimental flock of the Laboratory at Jouy-en-Josas were found to contain a certain proportion of individuals with abnormally high water consumption. A summing up of the corresponding data showed that these individuals were very likely to be homozygous for a major recessive gene (BORDAs et al., in press). This gene seems analogous and possibly identical to that described by WILLIAMS and BUSS (I968); in particular, it is associated with a large increase in the water/feed ratio.

In view of the present experiment, breeding birds of both sexes issued from the two strains mentioned above were chosen in families containing individuals with high water intake. These breeding birds (5 males, each with 5 females) were mated without any discrimination according to their strain of origin. In april I976, they gave rise to two hatches separated by a two week-interval. The female progeny were kept, raised on floor and put at 16 weeks of age in individual cages in a climatized room at $20^{\circ} \mathrm{C}$, with ro hours darkness and 14 hours light per 24 hours. The feed was in the form of pellets. Age at first egg, egg number till mid-December (average duration from 1st egg about 3 months), body weight and two body measurements (wattle length and shank length) in this same period were noted. The age of birds at this date was about 9 months. Their total number was then 94 . They were tested during II successive days in the second half of December for their water intake, so as to identify their genotype for the " polydipsia " factor. In this same testing period, feces were collected over 48 hours (Starting from Io a.m.), weighed, then dried in an oven at $60^{\circ} \mathrm{C}$ during 48 hours to evaluate their dry matter.

This test allowed to identify two groups of hens, one with " normal " water intake opposed to another with obviously " excessive " intake. In this second group for the experiment we kept only birds with a value for water intake appreciably higher than the average of " normals " plus twice their standard deviation, as the previous result (BORDAS et al., in press) showed that such individuals could be considered, with a very high likelihood, as homozygotes for the postulated recessive gene. Individuals with a value close to the limit between the two groups were discarded.

Using this criterion, 24 pairs of full-sisters, one " normal ", the other " polydipsic ", both laying at the time of the test, were kept. During this first testperiod, beside the measurement of water intake, weight of feces and water in the 
feces, four consecutive eggs were weighed per hen, the albumen height and shell thickness (including membrane) were determined for each; then, on one egg per hen, yolk weight, shell weight and albumen weight (the last by difference from total egg weight) were measured. Finally the hematocrit value was determined for each hen and one measurement was made (always around 2 p.m.) of its rectal temperature, along with superficial temperatures for comb (central zone) and shank (at mid-length). These temperatures were read to the nearest. $\quad{ }^{\circ} \mathrm{C}$ with a thermocouple connected with two different probes, one for rectal and another for superficial temperatures.

The 48 hens forming these 24 pairs, remaining in individual cages in the same cell, were then submitted, from 6th to I4th January 1977 inclusive (after a progressive rise of temperature from January 3 rd to $6 \mathrm{th}$ ), to a temperature cycle per day consisting of ro hours at $27^{\circ} \mathrm{C}$ during the dark period followed by $\mathrm{I} 4$ hours at $34^{\circ} \mathrm{C}$ during the lighted period. Percentage humidity was kept around $5^{\circ} \mathrm{p}$. cent as far as possible.

During this " heated " period, with this temperature cycle, again individual water consumption was recorded, and feces were collected over 48 hours, weighed and put to the oven as previously for determination of dry weight. The same egg traits and components as in the first test period were measured (albumen height and shell thickness on 2 eggs per hen, yolk, shell and albumen weight on one) as well as rectal, comb and shank temperature, each being taken once for each individual at the end of the period (around 2 p.m. in the day). Moreover, the respiration rate was noted per hen on each of the last three days of the " heated " period, alsc around $2 \mathrm{p} . \mathrm{m}$. for half a minute and doubled to get values per minute.

Each of the 48 studied females can be considered as having been submitted to two successive environments :The first one includes the whole period where ambient temperature was $20{ }^{\circ} \mathrm{C}$ (also called " normal " environment) and more specifically the test period in December. Some measurements were taken only in this phase (age at first egg, egg number till December, body weight and measurements, hematocrit). The second environment comprises the period from January 6 to $\mathrm{I} 4$, I977 with the daily cycle of temperature $\left(27-34^{\circ} \mathrm{C}\right)$. We will refer to it also as " heated environment " or by the abbreviation " at $34{ }^{\circ} \mathrm{C}$ " (although this temperature concerns only the lighted period).

A number of traits are measured in both environments as already mentioned (water intake, weight and percent water in feces, body temperatures, egg traits and components). Conversely, the egg number registered in the " heated " period is not comparable to that noted in the first environment (later stage in the laying year, short duration) and respiration rate is not measured at $20{ }^{\circ} \mathrm{C}$.

In the following tables, as concerns traits measured several times for each individual (egg traits, respiration rate), only the mean value per bird is used.

The traits measured in one or both of the environments are symbolized in an abbreviated way in the text and tables, as shown in the following list: 
Symbol and description of the characters used

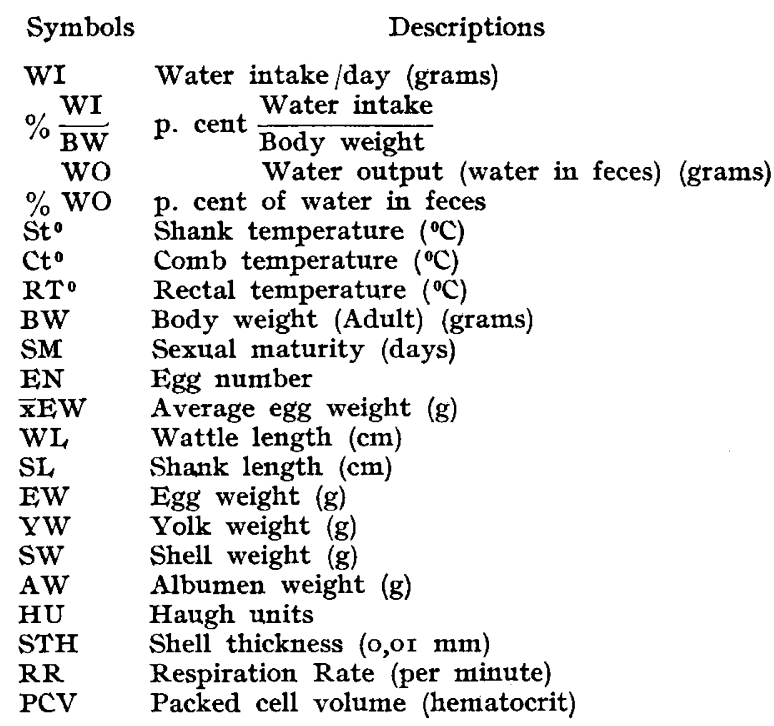

\section{Results}

Table $x$ gives the data characterizing water intake and water output for the two genotypes in the two envitonments. These two genotypes will be designated in abbreviated way as (di) for polydipsic and (Di) for normals.

Table 2 shows internal and superficial temperatures, P.C.V. at $20^{\circ} \mathrm{C}$ and R.R. at $34^{\circ}$ for (Di) and (di) birds, table 3 the productive traits, Table 4 the egg weights and egg components weights at the two temperatures. Tables I, 2, 4 contain analysis of variance for each trait with treatments, genotypes and sire families as sources of variation.

Finally Tables 5 to 8 include the phenotypic correlations between the different traits studied, within genotypes (Di or di) and environments.

\section{Discussion}

\section{I. - Water intake and output}

The difference between the two genotypes under study for water consumption proved to be highly significant (table $\mathrm{I} a$ and $b$ ) at $20{ }^{\circ} \mathrm{C}$. Buss (I968) reported that water intake depends on a mutant gene: a recessive autosomal gene causes excessive water intake. EwALD et al. (I967) and LIFschiTz et al. (I967) found statistically significant differences among and within individuals and between sexes for water consumption. Possibly, the presence of the mentioned recessive autosomal gene in some stocks may cause the difference between strains and individuals. 
TABLE I

Water intake and water output for the two genotypes (di) and (Di) at $20{ }^{\circ} \mathrm{C}$ and $34{ }^{\circ} \mathrm{C}$ Ingestion et excrétion d'eau pour les deux génotypes (di) et (Di) à $20{ }^{\circ} \mathrm{C}$ et $34^{\circ} \mathrm{C}$ a) " $t$ » test

\begin{tabular}{|c|c|c|c|c|c|c|c|c|}
\hline & & 20 & ${ }^{\circ} \mathrm{C}$ & & & & & \\
\hline & WI & $\% \frac{W I}{B W}$ & wo & $\%$ WO & WI & $\% \frac{W I}{B W}$ & wo & $\%$ wo \\
\hline (di) & 637.0 & 24.86 & 219.5 & $8 \mathrm{I} .9 \mathrm{r}$ & 744.0 & 29.73 & 289.3 & 89.84 \\
\hline (Di) & 343.6 & I 3.26 & I64.9 & 76.40 & 537.5 & $20.9 \mathrm{I}$ & 271.0 & 86.71 \\
\hline$\vec{d} . \quad \cdot$ & 293.4 & x 1.60 & 54.6 & 5.52 & 206.5 & 8.82 & $\mathrm{I} 8.3$ & 3.13 \\
\hline$" t n$. & $12.95\left(^{* *}\right)$ & $10.47(* *)$ & $2.15\left(^{*}\right)$ & $\mathrm{I} .90$ & $3.16\left({ }^{*}\right)$ & $3.20\left(^{*}\right)$ & 0.62 & $I .42$ \\
\hline
\end{tabular}

( $d$ is the differences between the two genotypes).

b) Analysis of variance

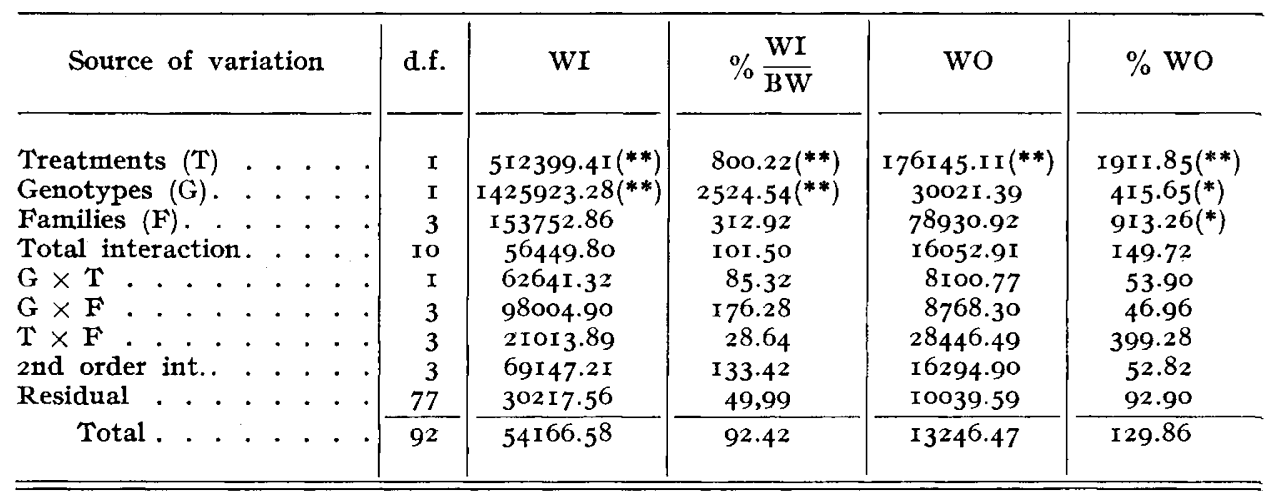

(*) Significant at 5 p. cent level.

$(* *)$ Significant at $\mathrm{I}$ p. cent level.

At $34^{\circ} \mathrm{C}$ the differences, for water intake, between the two genotypes decreased about one third. The same trend, almost, can be observed for water intake as. a percentage to body weight.

The differences between the two genotypes for water output and percentage of water in feces proved to be significant in normal conditions $\left(20^{\circ} \mathrm{C}\right)$. In this respect, ROBERT et al. (I974) reported significant differences between I2 stocks. of white Leghorns. The value of percent moisture for the I2 stocks were within the normal range, which averages about $70 \mathrm{p}$. cent, but can reach at maximum $82 \mathrm{p}$. cent in the normal birds and as high as $98 \mathrm{p}$. cent for polydipsic (SUE-LIN *. TERNMOORE, I972). 
In the hot environment, water output in the feces becomes little different for the two compared genotypes. Possibly the difference between the two genotypes in total water output may have been somewhat underestimated because of occasional projection of droppings of (di) hens into the trays collecting feces of neighbouring normal hens.

At $34^{\circ} \mathrm{C}$, the increase in water intake for the (di) birds is ro7.o (g) and the increase in water output is 69.7 (g). The increase for the (Di) birds, in water intake, is $193.8(\mathrm{~g})$ and $106.0(\mathrm{~g})$ in water output. These differences due to temperature proved to be highly significant (Table $\mathrm{I} b$ ). According to heat stress the birds consume more water for both genotypes to maintain body temperature as is well known (e.g. see Toshio et al., I970; SNETsinger, I975); but although the interaction term is not significant in the variance analysis the increase in water intake for the normal birds is about double the increase for the polydipsic. This may be due to the fact, that as the normal birds consume, in normal condition, less water than the polydipsic the latter need less increase in water consumption. Our data seem in agreement with the results obtained by SUE LINTERN-MOORE (I97I), that wet droppings are result of primary polydipsia rather than obligatory loss of body water followed by an increase in water intake.

It must be noted, finally, that there is no significant difference between families, except for percentage of water in feces, and no significant interactions as already mentioned.

\section{2. - Body temperature and respiration rate}

The difference between the mean values for rectal temperature, for the two genotypes (Table 2) proved to be significant only at normal temperature. On the other hand, the differences between the measurements at $20{ }^{\circ} \mathrm{C}$ and $34{ }^{\circ} \mathrm{C}$, which proved to be highly significant (Table $2 b$ ), for comb, shank and rectal temperatures are for (di) birds $4.12{ }^{\circ} \mathrm{C}, 6.75^{\circ} \mathrm{C}$ and $0.17^{\circ} \mathrm{C}$ respectively, and for (Di) they are $4.19^{\circ} \mathrm{C}, 7.4 \mathrm{I}{ }^{\circ} \mathrm{C}$ and $0.20^{\circ} \mathrm{C}$ respectively. Although, again, there is no significant interaction, one can remark that the differences on the (Di) birds are slightly higher than those of the (di) birds. In fact, body temperature rises above normal depend on the relative humidity of the atmosphere and the degree of acclimatization of the birds. Wrison (I948) found that rectal temperature increased at environmental temperature above $26.5{ }^{\circ} \mathrm{C}$ although the increases were small until the environmental temperature was $32.3^{\circ} \mathrm{C}$. LEE et al. (I945) noted that up to an environmental temperature of $29.5^{\circ} \mathrm{C}$ rectal temperature was unaffected but an environmental temperature of $32.3{ }^{\circ} \mathrm{C}$ increased body temperature by $0.20{ }^{\circ} \mathrm{C}$ to $0.83^{\circ} \mathrm{C}$.

The difference between the mean values of the two genotypes for respiration rate at $34^{\circ} \mathrm{C}$. proved to be the only significant one. The (di) birds are less panting than the normal birds (I); the increase in respiration rate, here, for the (Di) birds has the effect of lowering body temperature by evaporation. LoNGHOUsE et al. (I960) found that pullets kept at $32.3^{\circ} \mathrm{C}$ lost 60 p. cent of their body heat by evaporation. Total heat loss from laying hens due to respiration is relatively constant below $26.7^{\circ} \mathrm{C}$ ambient. Between $26.7^{\circ} \mathrm{C}$ and $3^{\circ}{ }^{\circ} \mathrm{C}$ it increases rapidly.

(r) In a further experiment on other hens kept in cages with the same temperature cycle $\left(27^{\circ} \mathrm{C}\right.$ during ro hrs darkness, $34^{\circ} \mathrm{C}$ during 14 hrs light) from april to june 77,9 additional pairs of sisters were obtained, one " normal ", the other " polydipsic ". Average respiration rate $/ \mathrm{mn}$ was 126.2 for the normals and ro6.9 for the polydipsic $(t=4.37, \mathrm{P}<0.01)$ which is in concordance with the present results. 
TABLE 2

Comb, Shank and rectal temperatures, P.C.V. and respivation rate for the two genotypes Températures de la crête, des tarses et rectale, hématocrite et rythme vespiratoire pour les deux génotypes a) " $t$ " test

\begin{tabular}{|c|c|c|c|c|c|c|c|c|}
\hline & \multicolumn{4}{|c|}{$20^{\circ} \mathrm{C}$} & \multicolumn{4}{|c|}{$34^{\circ} \mathrm{C}$} \\
\hline & $\mathrm{Ct}^{0}$ & Sto & $\mathrm{Rt}^{0}$ & P.C.V. & $\mathrm{Ct}^{0}$ & $\mathrm{St}^{0}$ & $\mathrm{Rt}^{0}$ & RR \\
\hline (di). . & 33.94 & 32.46 & $4^{0.93}$ & 29.22 & $3^{8.06}$ & $39.2 \mathrm{I}$ & 41.10 & 95.88 \\
\hline$\overline{(\mathrm{Di}) .}$ & 34.21 & 31.84 & 40.84 & 30.26 & 38.40 & 39.25 & 41.04 & 113.12 \\
\hline $\bar{d} .$. & -0.27 & $0.6 \mathrm{I}$ & 0.09 & $-\mathrm{r} .04$ & -0.34 & -0.04 & 0,05 & $-\mathrm{I} 7.24$ \\
\hline$" t »$. & 0.43 & I. 25 & I. $96\left(^{*}\right)$ & 1.40 & 0.44 & -0.28 & 0.47 & $2.27\left(^{*}\right)$ \\
\hline
\end{tabular}

b) Analysis of variance for the three body temperatures

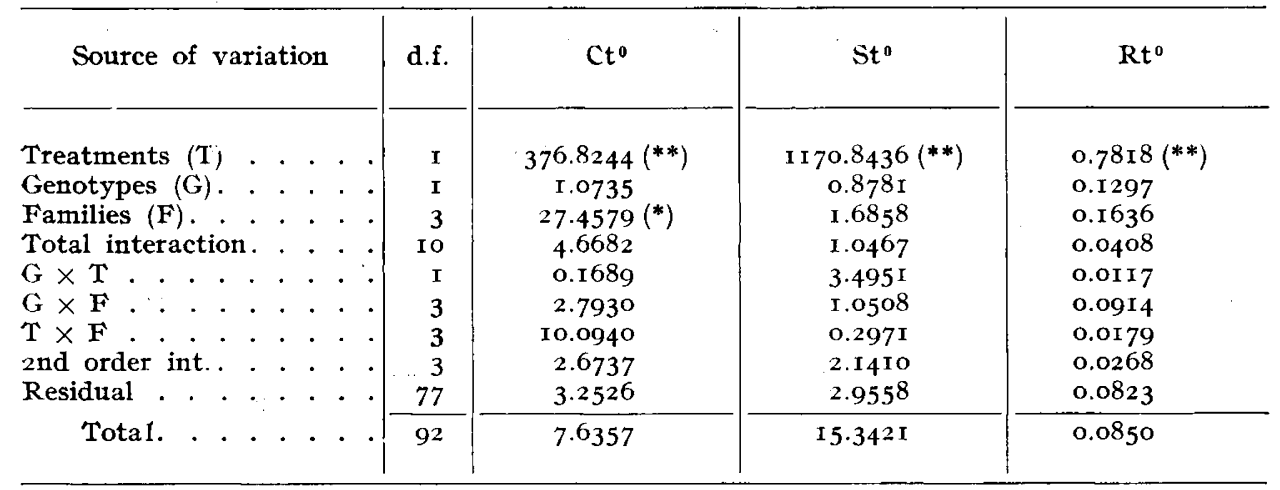

c) Analysis of variance for respiration rate and P.C.V.

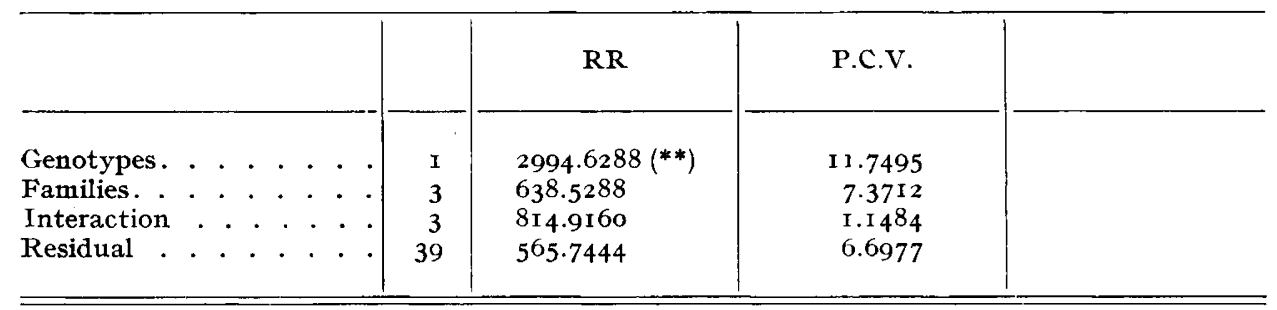

Above $32{ }^{\circ} \mathrm{C}$ the rate of increase declines, indicating a breakdown in the body temperature control mechanism (BAROTT and PRINGLE, I94I). The amount of increase of water loss by hens can be from $5(\mathrm{~g})$ per hour at normal temperatures up to $30(\mathrm{~g})$ per hour when the bird is panting (LEE et al., I945). 
TABLE 3

" $t$ " test for the productive traits according to the two genotypes and the two environmental temperatures Test t pour les caractères de production pour les deux génotypes aux deux températures ambiantes

\begin{tabular}{|c|c|c|c|c|c|c|}
\hline & \multicolumn{4}{|c|}{$20^{\circ} \mathrm{C}$} & \multicolumn{2}{|c|}{$34^{\circ} \mathrm{C}$} \\
\hline & $\begin{array}{l}\text { egg number } \\
\text { for } 3 \text { months }\end{array}$ & $\begin{array}{c}\text { average egg } \\
\text { weight }\end{array}$ & $\begin{array}{c}\text { sexual } \\
\text { maturity }\end{array}$ & $\begin{array}{c}\text { adult } \\
\text { weight }\end{array}$ & $\begin{array}{l}\text { egg number } \\
\text { for } 8 \text { days }\end{array}$ & $\begin{array}{c}\text { average egg } \\
\text { weight }\end{array}$ \\
\hline (di)... & $3^{8.52}$ & $6 \mathrm{r} .88$ & 203.22 & 2519.6 & $4 \cdot 17$ & 61.90 \\
\hline (Di) . . & 32.17 & $59.3 \mathrm{I}$ & 206.70 & 2605.2 & 2.74 & 58.10 \\
\hline $\bar{d} \ldots$ & 6.35 & 2.57 & $-3.4^{8}$ & -85.6 & $\mathrm{I} .43$ & 3.80 \\
\hline$\|t\|$. & 1.22 & I. $98\left(^{*}\right)$ & 0,55 & $\mathrm{I} .2 \mathrm{I}$ & $2.42(*)$ & $2.5 \mathrm{I}\left({ }^{*}\right)$ \\
\hline
\end{tabular}

From the above mentioned results, it can be concluded that the polydipsic birds are more tolerant to high environmental temperature since they show lesser increase in respiration rate, water intake and water output at high environmental conditions.

\section{3. - The productive traits}

Only mean values for egg weight proved to be statistically different in normal environmental temperature in favour of the (di) genotype. At $34^{\circ} \mathrm{C}$ the differences for egg number between the two genotypes proved, also, to be statistically significant in the same trend in spite of the short period of recording (only eight days). The same holds true with egg weight; moreover, there are no much changes in the mean values, with respect to the two genotypes, between the two different environmental temperatures.

\section{4. - Egg weight and weights of egg components}

Egg weight and weights of egg components corresponding to the two genotypes at the two environmental temperatures are shown in Table 4. The mean values of egg weight, yolk weight, shell weight proved to be statistically different in favour of the (di) hens in normal conditions. At $34^{\circ} \mathrm{C}$, no character showed significant difference between genotypes. This investigation for egg weight and components, weights for the two different environmental temperatures does not seem to have been done before.

The differences between the mean values at the two environmental temperatures, which proved to be statistically significant as concerns egg components, are $3.02(\mathrm{~g}),-0,66(\mathrm{~g}),+0,78(\mathrm{~g}),+2.12(\mathrm{~g})$, and $3.88(\mathrm{~mm})$ for egg weight, yolk weight, shell weight, albumen weight and shell thickness with respect of the (di) genotype. With respect to the (Di) genotype, the differences are $-0.02(\mathrm{~g}),-\mathrm{I}, 49(\mathrm{~g}),+0.19(\mathrm{~g}),+0.55(\mathrm{~g})$ and $+3.74 \mathrm{~mm}$ for egg weight, 


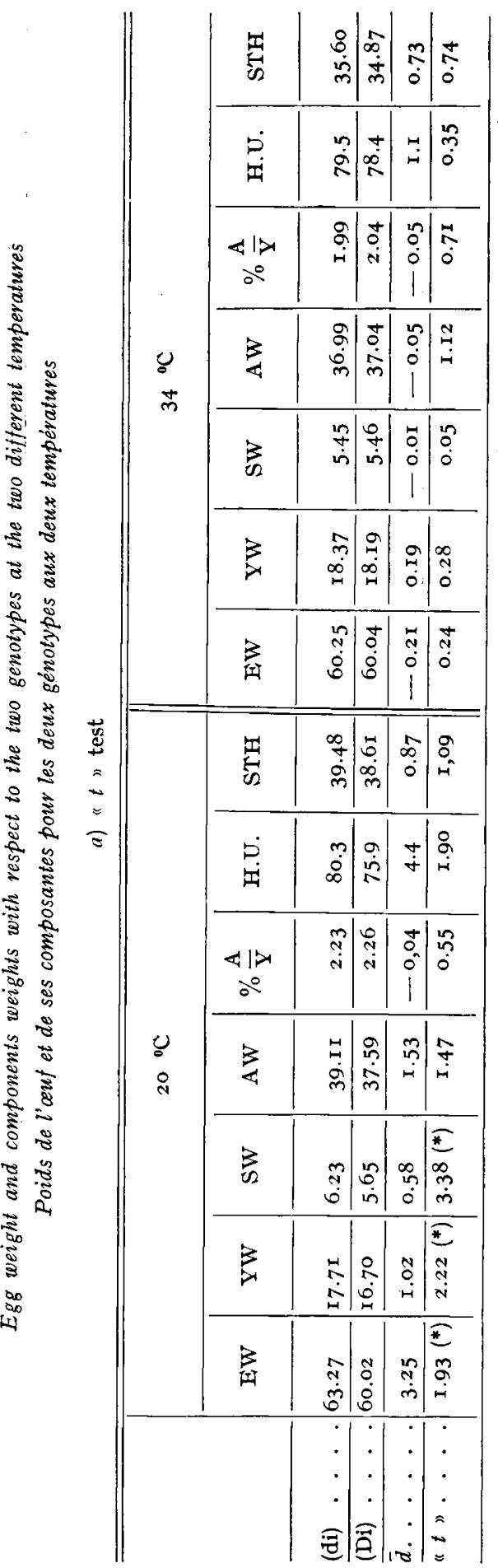

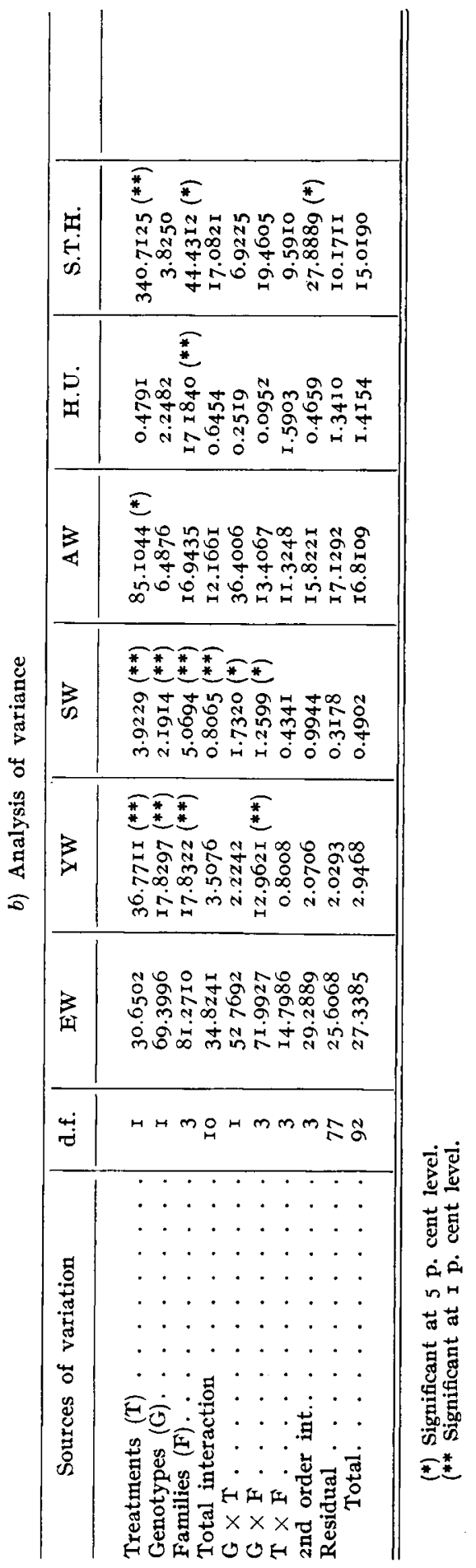




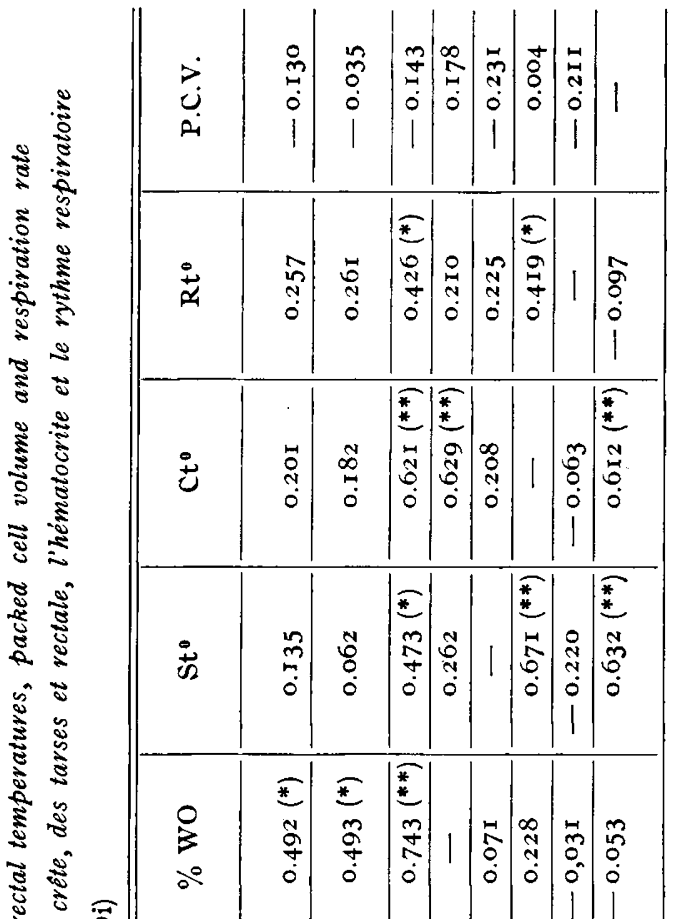

म

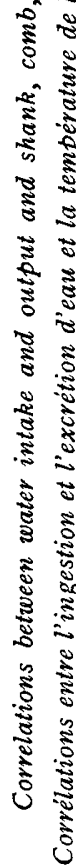

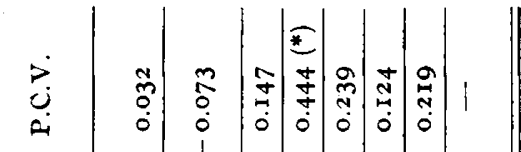

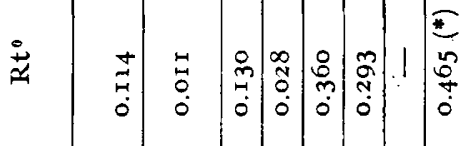

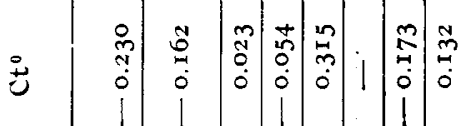

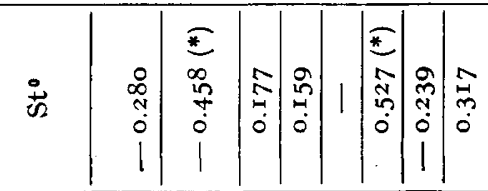

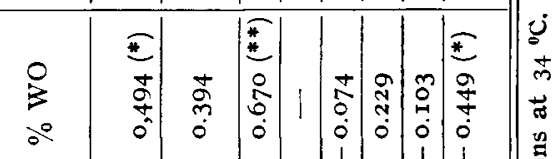

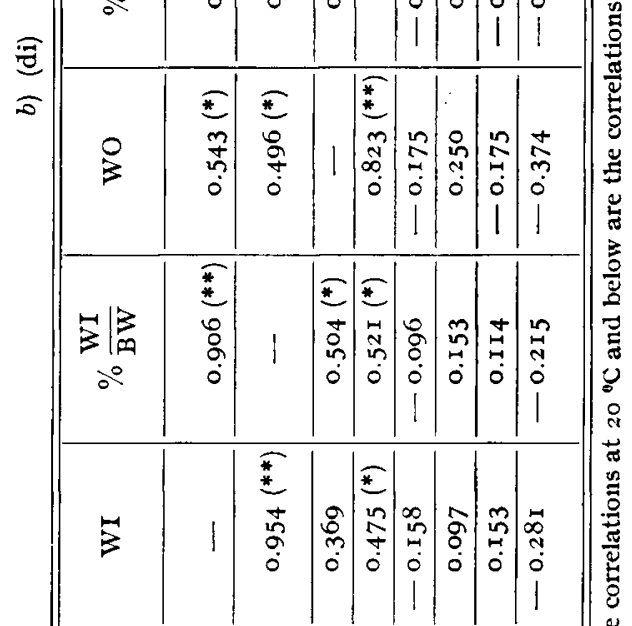


yolk weight, shell weight, albumen weight and shell thickness respectively. The decline in mean values for shell thickness has about the same magnitude for both genotypes. Shell weight and albumen weight are more depressed at heat stress for (di) genotype. Most of the decline in mean egg weight is due to the decline in albumen weight for this genotype. On the other hand, both means of the two genotypes, for yolk weight, are increased, the magnitude of increase for the (Di) mean being higher than for the (di) mean. One must mention that there are no genotype $\times$ treatment interactions except for shell weight.

The modifications occurring for egg formation at heat stress may be due among other things to water metabolism. Additional experiments would be required to confirm this hypothesis and know more precisely the way of action of the " polydipsia" genotype on egg components in hot climate.

\section{5. - Correlation between water intake and output, and physiological parameters (shank, comb, rectal temperatures, packed cell volume and respiration rate) for di and $\mathrm{D} i$ genotypes at $20{ }^{\circ} \mathrm{C}$ and $34^{\circ} \mathrm{C}$}

Owing to the great number of traits recorded, the correlations are presented in four tables. Due to the limited numbers available, some of these correlations may need to be further checked on additional data.

In normal condition $\left(20^{\circ} \mathrm{C}\right)$, for both genotypes, water intake is correlated significantly with water in feces and percentage of water in feces (Table 5). Buss and MurPhy (I965) found statistically significant correlation for visual score of excreta and water/feed ratio of immature and mature birds. At $34{ }^{\circ} \mathrm{C}$ water intake, for the (Di) genotype, is significantly correlated with water output but not with percentage of water in feces. Water output is significantly correlated, for (di) genotype, with percentage of water intake to body weight at $34{ }^{\circ} \mathrm{C}$.

In normal condition, for (Di) genotype, only water output showed significant correlations with comb, shank and rectal temperatures. The same holds true with the correlation between percentage of water in feces and comb temperature. With respect to the (di) birds, the correlation between the percentage of water intake to body weight and shank temperature is negative, and the correlation between percentage of water in feces and packed cell volume is the only significant one.

At heat stress, shank temperature is correlated with water intake and output, comb temperature and respiration rate; also, comb temperature and respiration rate show a correlation of about the same magnitude for the normal birds. The (di) birds show another distinct result, respiration rate is negatively correlated with percentage of water in feces and positively with rectal temperature. It may be added to the suggested tolerance of the (di) birds to heat stress, that the increase in ambient temperature causing an increase in body and accordingly in rectal temperature, both respiration rate and percentage of water in feces regulate body temperature: see reviews of SMITH and OLIVER (I97I) and LEESON et al. (r976) on this subject. But the absence of correlation between RR and RT in (Di) birds suggests a lesser regulation potential of the former by the latter.

\section{6. - Correlations between water intake and output, comb, shank and rectal tem- peratures and the productive characters and two body measurements}

The correlations between water intake and output, comb, shank and rectal temperatures and the productive characters and two body measurements for the two genotypes at the two environmental temperatures are shown in table 6 . 


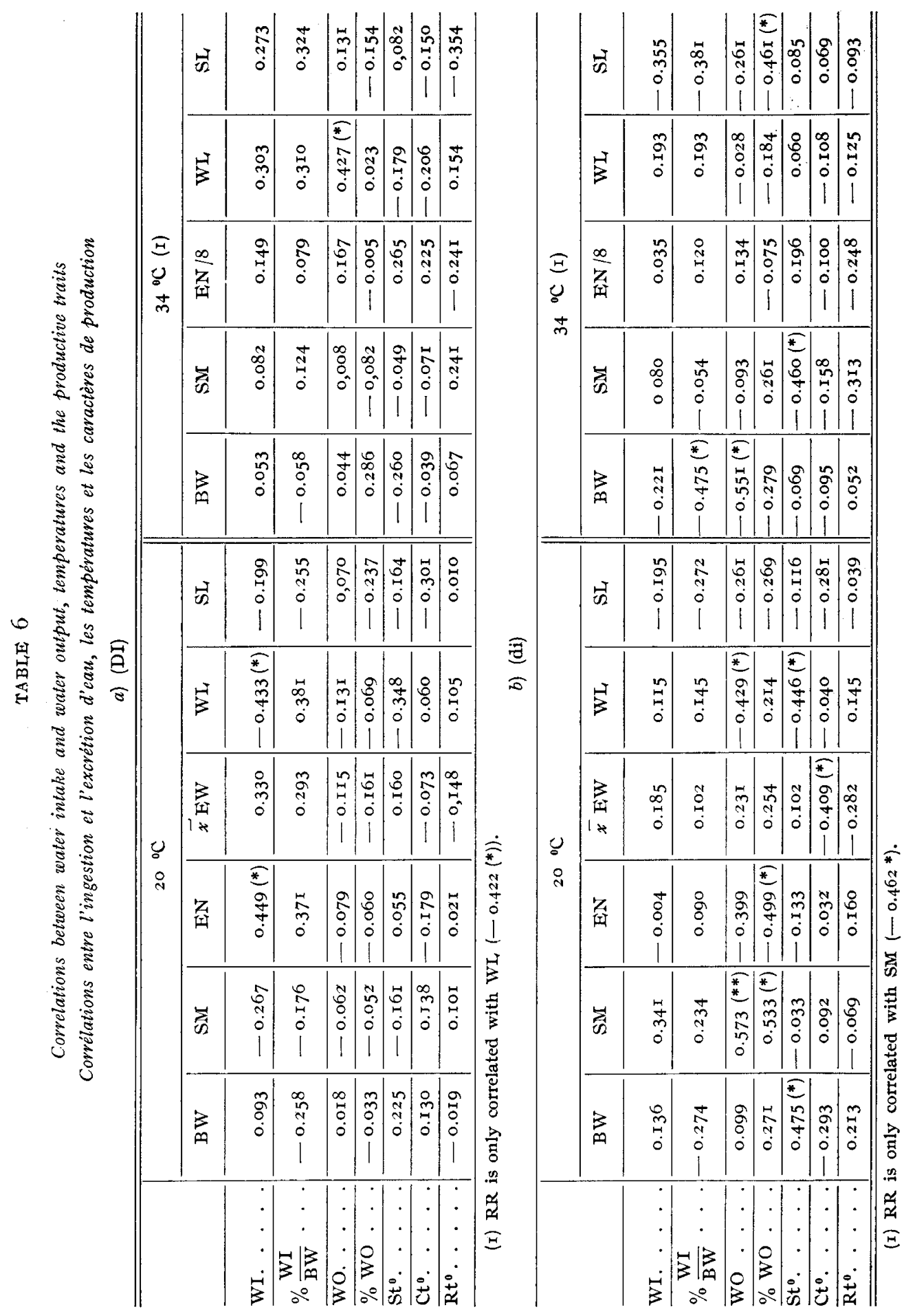




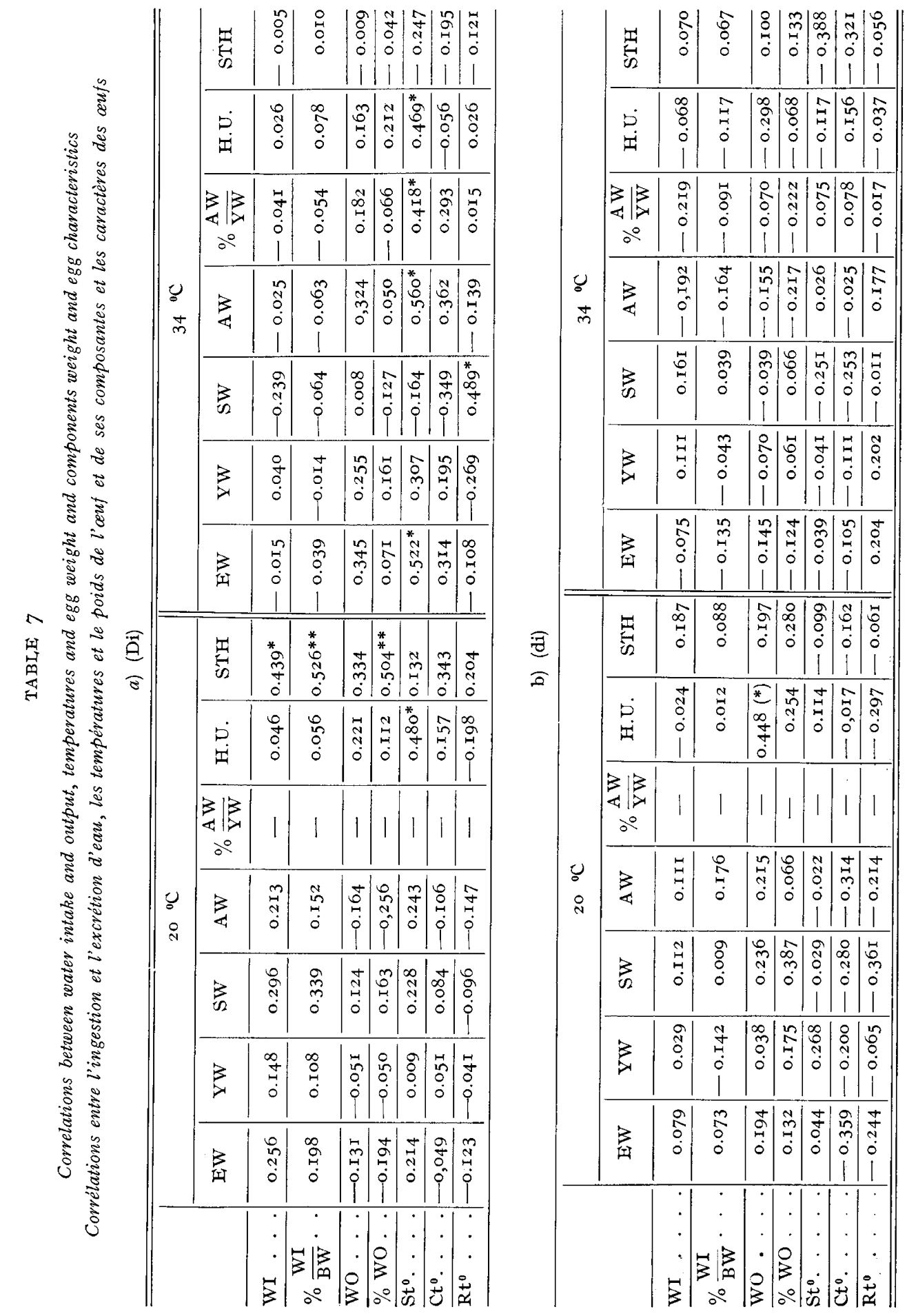


In temperate condition $\left(20^{\circ} \mathrm{C}\right)$, the correlation between egg number and water intake, for the (Di) birds, proved to be significant. Wattle length showed, also, significant correlation but with a negative sign. The (di) birds, in the same conditions, showed another trend. Water in feces and percentage of water in feces are correlated positively with sexual maturity; the two figures are of about the same magnitude. Wattle length is correlated negatively with water in feces. Egg number is correlated negatively with percentage of water in feces. So a higher percentage of water in feces decreases egg number for (di) birds, meanwhile, water intake increases egg number for the (Di) birds. On the other hand, for the (di) birds, shank temperature is correlated positively with body weight and negatively with wattle length, and rectal temperature is correlated negatively with average egg weight. ROBERT et al. (I974) found, for three lines of White Leghorns, that body weight was consistently positively correlated with dropping weight. Egg production was negatively correlated with percentage of fecal moisture and fecal wet weight which seems to agree with our results, especially those concerning the di birds. EWALD et al. (I967) noted that it is twice more effective to predict egg production through water ingestion rather than body weight. On the other hand, Buss and MURPHY (I965) noted that no statistically significant correlations were found for the water / feed ratio and egg number, egg weight, albumen quality, shell thickness and body weight.

At $34^{\circ} \mathrm{C}$, the (Di) birds showed a significant positive correlation between water in feces and wattle length, and a negative one $(-0.42)$ between wattle length and respiration rate. For the (di) birds, the correlation between body weight and water consumption in percentage to body weight and water in feces with body weight are negative (which anyway is expected for the first one). The same holds true with the correlation between shank length and percentage of water in feces and shank temperature with sexual maturity.

\section{7. - Correlations between water intake and output and egg weight and components weights and egg characteristics}

The correlations between water intake and output and egg weight and components weight for both genotypes at the two environmental temperatures are represented in Table 7 . Shell thickness is correlated positively with water intake, percentage of water intake to body weight and percentage of water in feces for the (Di) birds at $20^{\circ} \mathrm{C}$. The same holds true with correlation between shank temperature and Haugh units. Meanwhile, the (di) birds, in the same temperature condition, show a positive significant correlation between Haugh units and water output.

At heat stress only the Di birds showed positive significant correlations between shank temperature and egg weight, albumen weight, the albumen/yolk ratio and Haugh units.

\section{8. - Correlations between egg weight and egg components' weight with respect to the $D i$ and di genotypes in the two environmental conditions}

The correlations between egg weight and egg components weights and egg characteristics for the two genotypes under study at $20{ }^{\circ} \mathrm{C}$ and $34^{\circ} \mathrm{C}$ are shown in Table 8 . As egg weight is determined by it's component weights, it is normal 


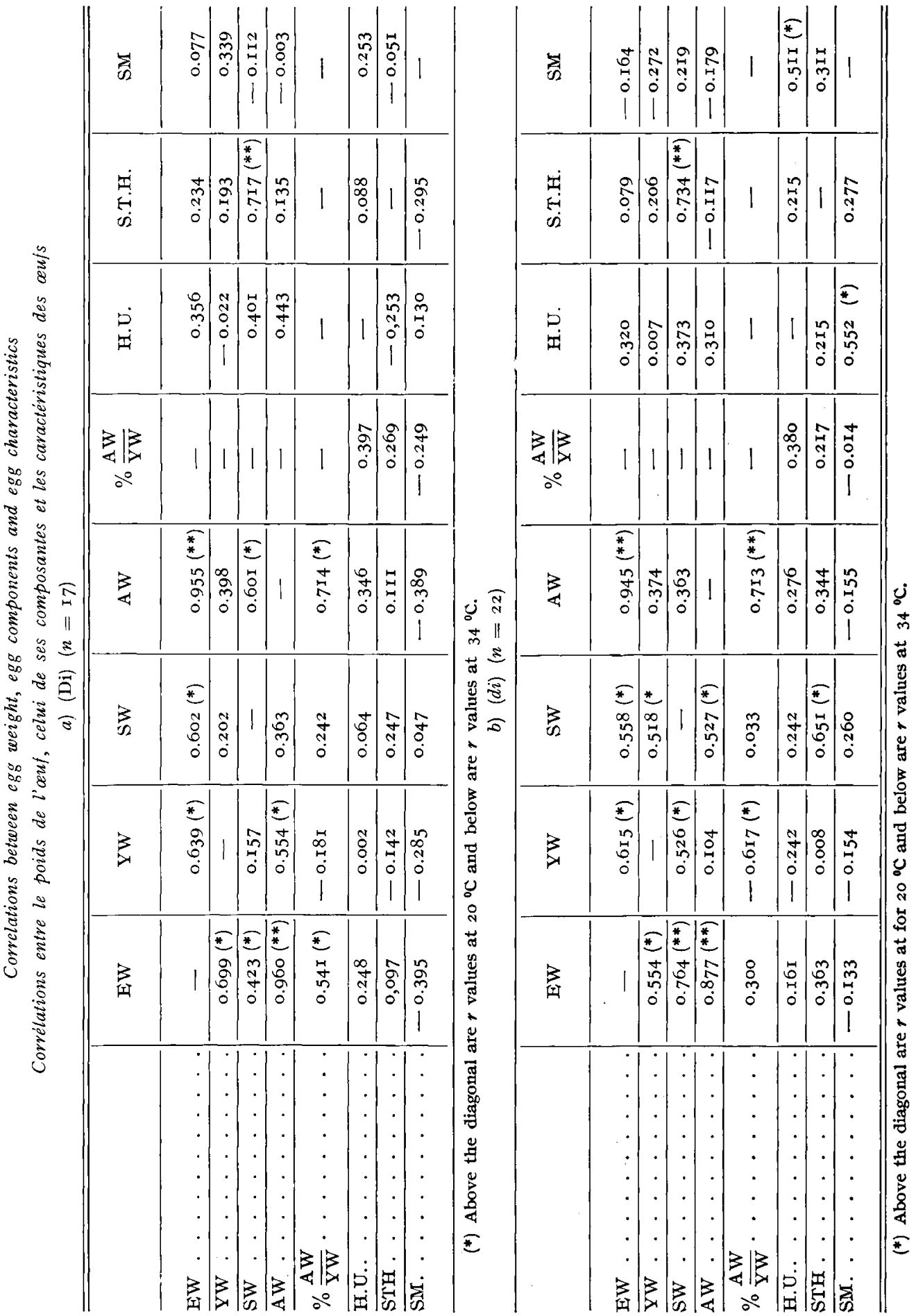


that the correlation between egg weight and components weights for the two genotypes in the two environmental conditions are positive and significant. The correlations between the components of the egg for the two genotypes in normal conditions are as follows: for (Di) birds yolk weight is not significantly correlated with both shell and albumen but shell weight is correlated with albumen weight, while, for (di) birds only yolk weight is correlated significantly with shell weight. Meanwhile, both genotypes show positive significant correlations, of about the same magnitude, between shell weight and shell thickness. OBEIDAH et al. (I977) showed in a study for $\mathrm{G}_{2}$ locus of egg white protein that the correlation between yolk weight and albumen weight existed for $G_{2} A B$ while there was no correlation for the $\mathrm{G}_{2} \mathrm{BB}$ genotype between the two characters, which may have some analogy with the present situation.

At $34^{\circ} \mathrm{C}$ the correlations changed as follows: for (Di) birds yolk weight is significantly correlated with albumen weight and for (di) birds shell weight is correlated with albumen weight. Meanwhile, the albumen /yolk ratio is correlated with both egg weight and albumen weight for the (Di) birds, while it is negatively correlated with yolk weight for the (di) birds. Another result in favour of (di) genotype is that in hot environment, still there is a significant positive correlation between shell weight and shell thickness which does not exist for the (Di) genotype. This may add to the efficiency of indirect selection for shell thickness for eggs produced by the (di) birds. Anyway the correlations seem to confirm that the gene for polydipsia has an appreciable effect on the components of the egg.

Rę̧u pour publication en décembre 1977.

\author{
Résumé \\ Polydipsie et polyurie à température ambiante élevée \\ en association avec les caractères de production chez la Poule
}

Ce travail avait pour but de rechercher les différences entre oiseaux normaux ou ayant une forte consommation d'eau et teneur des fèces en eau dans le troupeau expérimental de Jouyen-Josas, en association avec les caractères de production, des mensuration et températures corporelles et les composantes des cufs à deux températures ambiantes différentes. Les résultats peuvent être résumés comme suit :

I. La différence entre les deux génotypes (polydipsique et normal) pour l'ingestion d'eau se révèle hautement significative à la température " normale " $\left(20^{\circ} \mathrm{C}\right)$ et à la température élevée (cycle $27-34^{\circ} \mathrm{C}$ ), mais elle est plus importante dans le premier cas.

2. La différence entre les deux génotypes pour l'excrétion d'eau est significative en condition normale. Il en est de même de la température rectale.

3. Les températures corporelles (rectale, crête et tarses) sont augmentées significativement pour les deux génotypes à la température ambiante élevée.

4. Les poules polydipsiques présentent moins de respiration haletante que les normales dans l'environnement chaud.

5. Le poids de l'œuf et celui de ses composantes est plus élevé pour les poules polydipsiques en condition " normale".

6. Le nombre d'œufs est plus élevé pour les oiseaux polydipsiques dans la cellule chaude.

7. Les corrélations phénotypiques entre caractères sont estimées intra-génotypes et traitements. 


\section{Références}

Barott H. G. and Pringle E. M., 194I. Energy and gaseous metabolism of the hen affected by temperature. $J$. Nutr., 22, 273-286.

Bordas A., OBEIDAH A., MÉRAT P. On the heredity of water intake and feed efficiency in the fowl. Ann. Génét. Sél. anim. (in press).

Buss E. G. and Murphy R. R., I965. Methods of determination, assessment of possibly associated traits and evidence for genetic influence of excessive water intake by chickens. Poult. Sci., 44, I 358 (abstr.).

EwAld A. F., ERnesto L., Fanny M. and Oswaldo G., 1967. Individual differences in water ingestion and its association with egg production in poultry. Bol. Genet. Inst. Filotec. Castelar, $3, \mathrm{I}-7$.

LEE D. H. K., Rodinson E. W., YeAtes N. I. M. and ScotT M. R., i945. Poultry husbandry in hot climates. Experimental enquiries. Poult. Sci., 24, 195-207.

LEESON S., SUMmers J. D. and MCRAN E. T. Jr., 1976. Avian Water metabolism a review. World's Poult. Sci. J., 32 (2), I85-195.

Lifschitz E., German O., Favre't E. A. and Manso F., I967. Differences in water ingestion associated with sex in poultry. Poult. Sci., 46, го2 1-1023.

LoNGhouse A. D., OTA N. and Ashby W., I960. Heat and moisture design data for poultry housing. Agric. Engng., 41, 567-576.

Obeidail A., MÉRat P., DURAND L., I977. Polymorphism of egg white proteins and egg weight and components weights in Fayoumi. Ann. Génét. Sél. anim., 9, zor-306.

ROBER'T O. H., WiLliam T. C. and JAMES A. A., I974. Genetic differences in fecal output and their association with economic traits in the chickens. I5 th World Poult. Con., New-Orleans, 268-269.

Smith A. J., and Oliver J., I97I. Some physiological effects of high environmental temperature on the laying hen. Poult. Sci., 50, 912-925.

SNETSINGER D. C., I973. Water, an important nutrient. Checkerboard service. Ralston Purina Ltd. St Louis, USA.

SUE LINTERN-MOORE, I972. The relationship between water intake and the production of "wet" droppings in the domestic fowl. Br. Poult. Sci., 13, 237-242.

Toshio Ito, TEsshu M., SAdAki Y. and Ko Mimura, i97o. Effects of environmental temperature on egg production, Food intake and water consumption in laying White leghorns. Jour. of. Fac. of Fisheries and Anim. Husb., 9, I51-160.

WrLLIAM A. D. and BUSS E. G., I968. Abnormal water balance in a mutant strain of chickens. Science, 161, I67-169.

WILSON W. O., I948. Some effects of increasing environmental temperature on pullets. Poult. Sci., 27, 81 3-8I 7 . 